\title{
The Impact of Training and Development on Employee Performance of Apparel Industry in Sri Lanka
}

\author{
D. D. Gammanpila ${ }^{1}$ \& K.A.M.S. Kodisinghe ${ }^{2}$ \\ ${ }^{1,2}$ Department of Business Management \\ Faculty of Business Studies \& Finance \\ Wayamba University of Sri Lanka \\ Kuliyapitiya \\ SRI LANKA \\ dasanthagammanpila@gmail.com, kodisinghe@wyb.ac.lk
}

\begin{abstract}
The main objective of the study is to identify how training and development affects operational level employee performance in the context of the apparel industry in Sri Lanka. The researchers carefully chosen three leading apparel sector companies in Sri Lanka for this study. The reason for selecting this research topic is that it was identified that apparel companies were facing issues where employees make errors and delays and their performance has significantly reduced. It was identified that there are mistakes and delays from machine operators' side which affects target achievement, thereby shipment delays to the end customer. Over the last year, there was an error rate of 5 percent which causes a massive waste of materials and fabric. Key performance indicator achievement fell by 10 percent which hit revenue adversely and this has led to customers delaying payments and moving on to competitors who are more punctual. This demonstrates the importance of training and development which will reduce errors, mistakes and delays. The independent variables considered were orientation training, coaching, job rotation, mentoring and continuous job training while the dependent variable was employee performance in the apparel industry. A structured questionnaire was used to gather data which was distributed to 210 respondents who were selected on convenience sampling. The findings denoted that there is a strong positive impact of all independent variables on the dependent variable.
\end{abstract}

Keywords-: Training and Development, Employee Performance, Apparel industry

\section{INTRODUCTION}

\subsection{Background of the Study}

At present, every organization is operating in rapidly changing and very competitive environment as per Ardley \& Mcintosh (2019). They further elaborated that every company may have to face global, economics and technological changes when operating their business activities. Hence, organizations have to update and enhance the knowledge, skills, attitudes and capabilities of employees' in order to 
achieve organizational objectives. Sultana (2012) demonstrated that the purpose of human resource management is to enhance employee contribution to the organization and develop the employees. In this context, training and development plays a vital role. Human capabilities are changing day by day, therefore, if companies fail to give training to their employees in order to upgrade skills, knowledge and attitudes they may leave the organization (Aidah, 2013). As per Charles (2009), apparel technology keeps getting updated frequently. Therefore, training and development is a crucial aspect in enhancing skills and competencies of employees, thereby increasing performance of the employees' as mentioned by Juliana (2004).

It was identified that lack employee performance is a severe issue in the apparel sector in Sri Lanka as organizations lose a considerable amount of revenue when employees do not perform well. Three leading apparel companies in Kurunegala district were selected for this research and it was identified that there are mistakes and delays from machine operators' side which affect target achievement, thereby shipment delays to the end customer. Over the last year, there was an error rate of 5 percent which causes a massive waste of materials and fabric (X, personal communication, 05 February 2020). This has led to customers delaying payments and moving on to competitors who are more punctual. It demonstrates the importance of training and development which will reduce errors, mistakes and delays. Thus, identifying the ways and means to increase employee performance is vital which will be analyzed through literature and then be researched in the context of the apparel industry in Sri Lanka.

Although various researches have been carried out to identify the impact of training and development on employee performance, factors such as orientation training, coaching, job rotation and mentoring have not been focused. Most researchers have focused on self-efficacy, communication, support, working conditions and quality of trainers which are not factors directly under the umbrella of training and development and this was identified as a research gap in this study.

\subsection{Research Objective}

The objective of this study is,

- To identify how training and development affects employee performance in the context of the apparel industry in Sri Lanka.

Further, it was cascaded into specific objectives as follows;

- To investigate the impact of orientation training, coaching, job rotation, mentoring and continuous job training on employee performance.

The study is limited to the impact of training and development on the job performance of employees in the apparel industry in Sri Lanka. Furthermore, the study was limited to selected employees of three major apparel companies as a focus point 
which are Company A, B and C. The study carried out was quantitative which covered 10 percent of employees per organization, making the total sample 210. The selected factors for analysis of impact of training and development on the job performance of employees are orientation training, coaching, job rotation, mentoring and continuous job training.

\section{Employee Performance}

Juliana (2004) defined performance as the accomplishments or the outcomes produced by the behavior we value. Raymond (2010) mentioned that performance can be measured and analyzed by human resource development professionals to determine whether the organizational objectives are being met. Abdul (2011) pointed out that once performance is measured, it could be compared against the planned level of performance in order to identify gaps.

\subsection{Training}

Armstrong (2006) demarcated training as a systematic development of the knowledge, skills and attitudes required by an individual to perform adequately a given task or job. According to the Flipp (1984), "training is the act of increasing knowledge and skills of an employee for doing a particular job". The term 'training' indicates the process involved in improving the aptitudes, skills and abilities of the employees to perform specific jobs. Training helps in updating old talents and developing new ones. It is vivid that training will enhance the skill sets of employees. Hence, it is evident that training and development plays a vital role in the successful functioning of the organization. Carrying out training and development will facilitate in addressing gaps in performance which will in turn assist in achieving the KPIs. Tahir (2014) identified that there is a positive relationship between training and development and employee performance. As per him, one major reason for employees to underperform is when they are not aware of what they have to do. It can be mentioned that when employees are clear as to what is expected of them and possess the skills and competencies to do so, job performance will consequently increase.

\subsection{Employee Development}

Employee Development is one of the most important functions of human resource management as per Learner (1986). Employee development means to develop the abilities of an individual employee and organization as a whole as per them. Employee development consists of individual or employee and overall growth of the employee (Armstrong, 2006). This means when employees of the organization develop, the organization, organization would be more flourished and the productivity would increase (Elena, 2000). Consequently, there is a direct relationship between employee development and employee performance. Furthermore, when employees are more developed, they would be more satisfied with the job, 
more committed towards the job and as a result performance would be increased (Sims, 2006).

Employee development activities are very important for the employees, as the activities are performed, it indicates that organization cares about their employees and wants them to develop (Elena, 2000). Many of the organizations are investing in employee development. When organizations are contributing towards the employee development activities, the employees work hard and utilize their full skills and efforts to achieve the goals of the organizations. There are many schools of thoughts. One school of thought says that employee development focus on areas such as self-development and self-directed learning. This concept indicates that employee development must be recognized by the employees who want to learn or who are willing to learn. When employees are willing to learn, they show their interest in the developmental activities, as a result they are more satisfied with the job which will lead to increase in employee performance (Champathes, 2006). Employee development also depends upon the individual employee, how much curiosity to learn, no matter how much expertise does a person have if person or employee is not willing to develop, no matter how much resources you provide employee would not developed. So employee development is also a personal responsibility of the employees. Employees at all levels are involved in the developmental activities whether the upper level employees, middle or lower level employees (Champathes, 2006).

\subsection{Independent Variables}

\section{Orientation Training}

Orientation means providing new employees with basic information about the employer (Tuzun, 2005). As per Sims (1998), orientation and training programs are important components in the processes of developing a committed and flexible high potential workforce and socializing new employees. In addition, these programs can save employers' money, providing big returns to an organization, because an organization that invests money to train its employees results in both the employees and the organization enjoying the dividends (Sims, 1998).

Unfortunately, orientation and training programs are often overlooked (Albercht et al., 2015). A recent U.S. study, for example, found that 57 percent of employers reported that although employees' skill requirements had increased over a three year period, only 20 percent of employees were fully proficient in their jobs. According to Andrew (2012), orientation programs not only improve the rate at which employees are able to perform their jobs but also help employees satisfy their personal desires to feel they are part of the organization's social fabric. He further states that the HR department generally orients newcomers to broad organizational issues and fringe benefits. Supervisors complete the orientation process by introducing new employees to coworkers and others involved in the job. A buddy or mentor may be assigned to continue the process. 


\section{Coaching}

Coaching is an important activity for the employee development. Coaching is not formal. It involves treating employees as a personal partner in achieving both personal and organizational goals. Hence, we can solve personal problems of the employees by providing coaching (Agarwal, 2006). When problems are resolved, this lead to increase in organizational performance as employees would be able to achieve organizational goals. Azar \& Shafighi (2013) mentioned that coaching is one of the most critical skills to be mastered by today's entrepreneur. Today's environment has created more pressure to do more with less. The key to reducing pressure is to make the most of the employees. Coaching is the most effective way of developing employees. Improved employee performance leads to increased productivity and bottom line results. Employees experience increased self-esteem and job satisfaction (Azar \& Shafighi, 2013).

\section{Job Rotation}

According to Bukovinsky (2013), job rotation is a technique used by some employers to rotate their employees' assigned jobs throughout their employment. Research indicates that job rotation enables cost savings as well as increase performance of employees' as per him. By rotation of jobs, the employees feel stress free as they rotated to a new job which helps them to learn something new, and motives them to give performance. In the apparel industry by rotating employees, the employees workload reduced and they did not get bored by their same job, which ultimately motivates them and increase their performance (Carvin, 2011).

The employees take interest in new jobs as their jobs rotates as per time schedule (Bukovinsky, 2013). As the job rotates the employee got to a new position whether it is on the same rank but the nature of the job changes which creates his/her interest towards new job. According to Carvin (2011), this leads to increase in employees' performance. The self- promoting system in job rotating systems creates satisfaction for employees and give them greater exposure to all aspects of the job. Ideally, this would produce better products as managers or other employees gain knowledge on consumer needs while marketing people engaged in the banking services and can give their point of view as per Carvin (2011).

\section{Mentoring}

As per Choudhary et al. (2012), mentorship is a relationship in which a more experienced or more knowledgeable person helps to guide a less experienced or less knowledgeable person. They further mentioned that the mentor may be older or younger than the person being mentored, but they must have a certain area of expertise. Mentoring offers numerous benefits to both mentor and mentee. It serves to broaden staff insight into the business and build stronger relationships as per Brick (2012). Mentoring contributes to the success of the mentee by improving performance, increasing confidence, and addressing strengths and weaknesses (Brick, 2012). A 
mentorship can help a mentee learn and develop faster by encouraging an exchange of information that does not always exist naturally as stated by Albercht et al. (2015). Mentoring programs let employees know that the company values them and has an interest in their personal development, leading to increased productivity and reduction in turnover as per them.

\section{Continuous Job Training}

According to Densten and Sarros (2012), companies can reap the rewards of providing training for their employees because well-trained workers help increase productivity and profits. According to Densten and Sarros (2012), a continuous training program helps employees hone their knowledge and skills and provides them with a clear picture of their strengths and weaknesses. From an organizational perspective, it also minimizes weak points and saves your business time and money by avoiding repeat mistakes. Andrew \& Sofian (2012) stated that employees who have access to continuous training and mentorship programs are more likely to feel valued, engaged, and loyal to your business. They feel accomplished when tackling new challenges and are eager to learn more and advance their careers. Continuous training benefits employees and employers, providing them with the confidence, skills, and creativity needed to do superb work today, tomorrow, and many years down the line (Albercht et al., 2015).

After studying literature, it was identified that although various researches have been carried out to identify the impact of training and development on employee performance, factors such as orientation training, coaching, job rotation and mentoring have not been focused adequately. Most researchers have focused on self-efficacy, communication, support, working conditions and quality of trainers which are not factors directly under the umbrella of training and development. Furthermore, as per the data collected, the problem of lack of employee performance still persists. Productivity of organizations are deteriorating despite technological upgrades. The management takes efforts to address this through various strategies. Consequently, this research study was conducted to address this gap.

\subsection{Conceptual Framework}

\section{Training \& Development \\ Orientation \\ Training (OT) \\ Coaching $(\mathrm{CO})$ \\ Job Rotation (JR)}

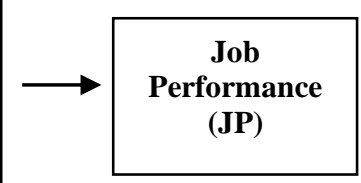

Figure 1: Conceptual Framework

Author Developed, 2020

\section{$1.7 \quad$ Hypotheses}

H1: Orientation training has a significant impact on Employee Performance in the apparel industry. $\mathrm{H} 2$ : Coaching has a significant impact on Employee Performance in the apparel industry. 
H3: Job rotation has a significant impact on Employee Performance in the apparel industry.

H4: Mentoring has a significant impact on Employee Performance in the apparel industry.

H5: Continuous job training has a significant impact on Employee Performance in the apparel industry.

\section{METHODS}

For this research a deductive approach was deemed suitable where it initiates with an in-depth review of literature to identify gaps in literature for which hypothesis will be formulated and tested. This will be a quantitative study where attention will be paid on collecting numerical data.

Under this research, the sample was 210 employees working in Company A, B and C. The study carried out was covered 10 percent employees per organization and making the total sample 210 . The table 1 presents how these employees were selected from each organization to form the sample. The sampling technique is convenience sampling which is a non-probability sampling technique where the respondents were selected based on easy accessibility.

Table 1: Total Sample

\begin{tabular}{|l|c|}
\hline \multicolumn{1}{|c|}{ Company } & Sample \\
\hline Company A & 92 \\
\hline Company B & 75 \\
\hline Company C & 43 \\
\hline Total Sample & 210 \\
\hline
\end{tabular}

Source: Survey Data, 2020
This is a quantitative research where attention will be on numerical figures. A survey strategy was selected as it facilitates gathering a massive amount of data. A questionnaire was used collecting data which comprises of five point likert scale questions.

Both primary and secondary data were used in this study. In this research a structured questionnaire was used to collect primary data under factors such as orientation training, coaching, job rotation, mentoring and continuous job training, in order to identify their impact on job performance. Several secondary sources such as journal articles, research papers, reviews, newspapers, magazines, blogs and books was used. Accredited sources such as Emerald Insight, Elsevier, Sage, JSTOR, Springer were used.

SPSS 22 was used to carry out the calculations and analyses. It was used to generate graphs, charts and tables. Descriptive analysis, correlation analysis and regression analysis were employed for further analysis.

\section{RESULTS}

\subsection{Reliability Testing}

The reliability analysis results are tabulated below where the values of Cronbach's alpha are greater than 0.7 as clearly presented in the Table 2 . Hence, it could be realized from this that the data is reliable and suitable to continue with hypothesis test and descriptive analysis. The results indicated below were obtained from SPSS. 
Table 2: Reliability Analysis

\begin{tabular}{|c|c|c|}
\hline Variables & $\begin{array}{c}\text { Cronbach } \\
\text { 's Alpha }\end{array}$ & $\begin{array}{c}\text { Decision } \\
\text { Rule }\end{array}$ \\
\hline $\begin{array}{c}\text { Orientation } \\
\text { training }\end{array}$ & 0.734 & $0.734>0.7$ \\
\hline Coaching & 0.874 & $0.874>0.7$ \\
\hline Job rotation & 0.912 & $0.912>0.7$ \\
\hline Mentoring & 0.745 & $0.745>0.7$ \\
\hline $\begin{array}{c}\text { Continuous } \\
\text { job training }\end{array}$ & 0.820 & $0.820>0.7$ \\
\hline
\end{tabular}

Source: Survey Data, 2020

\subsection{Normality Testing}

A normality test assist in understanding the Central tendency and the Dispersion of the Test variables which was carried out for this research. The Skewness and Kurtosis values were between +2 and -2 . Based on which it could be mentioned that the data is normally distributed.

Table 3: Normality Test Table

\begin{tabular}{|l|c|c|c|c|}
\hline Variables & \multicolumn{2}{|c|}{ Skewness } & \multicolumn{2}{c|}{ Kurtosis } \\
\cline { 2 - 5 } & $\begin{array}{c}\text { Statis } \\
\text { tic }\end{array}$ & $\begin{array}{c}\text { Std. } \\
\text { Error }\end{array}$ & $\begin{array}{c}\text { Statis } \\
\text { tic }\end{array}$ & $\begin{array}{c}\text { Std. } \\
\text { Error }\end{array}$ \\
\hline $\begin{array}{l}\text { Orientation } \\
\text { training }\end{array}$ & .321 & 0.248 & 1.142 & .341 \\
\hline Coaching & .306 & 0.136 & 1.200 & .322 \\
\hline Job rotation & 1.047 & 0.145 & .906 & .246 \\
\hline Mentoring & 1.463 & 0.304 & .208 & .254 \\
\hline $\begin{array}{l}\text { Continuous } \\
\text { job training }\end{array}$ & .414 & 0.274 & 1.574 & .201 \\
\hline
\end{tabular}

Source: Survey Data, 2020

\subsection{Demographic Analysis}

The gender analysis denoted that the male population in the industry is 48 percent while female population is $\mathbf{5 2}$ percent. It was identified that although females have more concerns such as inability to work at night, the company management prefers female as they are more organized and creative. The age analysis demonstrated that the majority of the employees are young. One reason could be that young employees are in high spirits whose thinking is innovative and creative which is important in apparel industry. As per the experience analysis, majority of the employees were less experienced. Apparel industry prefers young employees; therefore, their experience will also be lower in line with the age policy. The education analysis denoted that a greater majority of 65 percent were either advanced level qualified or partly qualified in a degree which too is in line with the age and experience analysis. These findings are in line with literature reviewed too as per Divina (2004) and Muthiani (2013).

Table 4: Hypotheses Testing

\begin{tabular}{|l|c|c|c|c|}
\hline Factor & Sig. & $\begin{array}{c}\text { Pearson } \\
\text { Corre. }\end{array}$ & $\begin{array}{c}\text { Standar. } \\
\text { Coeffici. } \\
\text { Beta }\end{array}$ & $\begin{array}{c}\text { Test } \\
\text { Result }\end{array}$ \\
\hline OT & $\begin{array}{c}0.00 \\
1\end{array}$ & 0.7561 & 0.712 & $\begin{array}{c}\text { H0;not } \\
\text { supported }\end{array}$ \\
\hline CO & $\begin{array}{c}0.00 \\
0\end{array}$ & 0.8140 & 0.801 & $\begin{array}{c}\text { H0;not } \\
\text { supported }\end{array}$ \\
\hline JR & $\begin{array}{c}0.00 \\
1\end{array}$ & 0.6846 & 0.671 & $\begin{array}{c}\text { H0;not } \\
\text { supported }\end{array}$ \\
\hline ME & $\begin{array}{c}0.00 \\
2\end{array}$ & 0.8462 & 0.815 & $\begin{array}{c}\text { H0;not } \\
\text { supported }\end{array}$ \\
\hline CT & $\begin{array}{c}0.00 \\
0\end{array}$ & 0.7820 & 0.762 & $\begin{array}{c}\text { H0;not } \\
\text { supported }\end{array}$ \\
\hline
\end{tabular}

Source: Survey Data, 2020

\subsection{Hypotheses Testing}

H1 - Orientation training has a significant impact on Employee Performance of the apparel industry in Sri Lanka. 
The Pearson correlation was 0.7561 denoting a positive relationship between independent and dependent variables. The beta $(\beta)$ value was 0.712 which reflect there is a strong positive impact of Orientation training on Employee Performance. Orientation training was statistically significant at 0.05 level $(\mathrm{P}=0.001<$ 0.05). Thus, the null hypothesis (H0) was not supported.

H2: Coaching has a significant impact on Employee Performance in the apparel industry in Sri Lanka.

The Pearson correlation was 0.8140 denoting a positive relationship between independent and dependent variables. The beta $(\beta)$ value was 0.801 which reflect there is a strong positive impact of coaching on employee performance. Coaching was statistically significant at 0.05 level $(\mathrm{P}=0.000<0.05)$. Hence, the null hypothesis (H0) was not supported.

H3: Job rotation has a significant impact on Employee Performance in the apparel industry in Sri Lanka.

The Pearson correlation was 0.6846 denoting a positive relationship between independent and dependent variables. The beta $(\beta)$ value was 0.671 which reflect there is a strong positive impact of job rotation on employee performance. Job rotation was statistically significant at 0.05 level $(\mathrm{P}=0.001<0.05)$. Thus, the null hypothesis (H0) was not supported.
H4: Mentoring has a significant impact on Employee Performance in the apparel industry in Sri Lanka.

The Pearson correlation was 0.8462 denoting a positive relationship between independent and dependent variables. The beta $(\beta)$ value was 0.815 which reflect there is a strong positive impact of mentoring on employee performance. Mentoring was statistically significant at 0.05 level $(\mathrm{P}=0.002<0.05)$. Hence, the null hypothesis (H0) was not supported.

H5: Continuous job training has a significant impact on Employee Performance in the apparel industry in Sri Lanka.

The Pearson correlation was 0.7820 denoting a positive relationship between independent and dependent variables. The beta $(\beta)$ value was 0.762 which reflect there is a strong positive impact of continuous job training on employee performance. Continuous job training was statistically significant at 0.05 level $(\mathrm{P}=0.000<0.05)$. Thus, the null hypothesis $(\mathrm{H} 0)$ was not supported.

\subsection{Discussion on Findings}

Orientation training - Orientation training and employee performance variables reflect a strong positive relationship of 75.61 percent. Grounded on this, it appears that orientation training contained useful information on the company history, structure profile, covered all the required information such as contact persons and floor tour, was well planned, timely, interactive and 
useful and tools used for the orientation training were effective. As per Charles (2009), orientation training programs are important in the processes of developing a committed and flexible high potential workforce and socializing new employees which will increase employee performance as they are likely to feel more comfortable in the organization right from the beginning. Hence, it could be stated that the findings are in line with the literature.

Coaching - Coaching and employee performance variables reflect a strong positive relationship of 81.4 percent. Based on this, it appears that the coach is able to understand questions raised and help find the right answers/ resources, communicates effectively, encouraging and motivating, encouraging and motivating and assists in clearing doubts. According to Armstrong (2006), coaching involves treating employees as a personal partner in achieving both personal and organizational goals which resolves problems of employees and in turn leads to increase in employee performance. Thus, it could be stated that the findings are in line with the literature.

Job rotation - Job rotation and employee performance variables reflect a strong positive relationship of 68.4 percent. Based on this, it appears that job rotation provided staff with a wider view on the process, an opportunity to get to know colleagues from other teams and share their knowledge and in understanding the bigger picture and performing a job role in a better manner. According to Bukovinsky (2013), rotating employees will reduce monotony of employees as they do not get bored by the same job, which ultimately motivates them and increase their performance. Hence, it could be stated that the findings are in line with the literature.

Mentoring - Mentoring and employee performance variables reflect a strong positive relationship of 84.62 percent. Based on this, it appears that mentoring program has contributed to better self-perception and understanding one's capabilities, workshops conducted were well planned, relevant to the job role and punctual and mentoring sessions were helpful in developing soft skills. Mentoring contributes to the success of the mentee by improving performance, increasing confidence and addressing strengths and weaknesses as highlighted by Abdul (2011). Thus, it could be stated that the findings are in line with the literature.

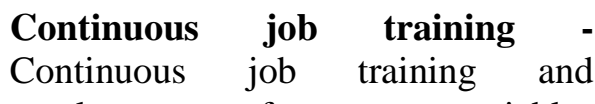
employee performance variables reflect a strong positive relationship of 78.2 percent. Based on this, it appears that continuous job training has assisted in polishing skills and competencies to stay up-to-date, inform on new technologies and work methods in the apparel industry and have built confidence in employees as they feel updated. According to Aidah (2013), training has to be carried out on a continuous basis as knowledge has to be continually updated. Although this comes with a cost attached, companies can reap the 
rewards of providing training for employees as well-trained workers contribute towards increasing productivity. Thus, it could be stated that the findings are in line with the literature.

\section{DISCUSSION}

Several recommendations can be made based on the data collected and analyzed in further improving the employee performance in the apparel industry. It can be recommended to enhance orientation training by including an off-the job training of the actual work that an employee will be performing on the floor before they are being dropped on floor. This could be done by creating a simulated work environment where employees will handling day to day work for a period of one week or so where they learn the challenges. They can be better prepared in settling down in the role which will improve their performance. It can also be recommended to bring down influential persons like the CEO or chairman of the company where an employee gets to spend time with them and ask questions. This will facilitate in setting down more comfortably as they already know the top management too.

It can be recommended to provide details regarding future coaching sessions at least two weeks prior to the sessions so that employees can be prepared to ask the doubts they have in a better manner. Coaching can be further improved by obtaining suggestions of employees regarding areas where they think coaching is needed. Talented and skilled resource persons could be arranged with preannounced date with the agenda so that employees will be able to free their schedules and make it to the session. This will improve employee performance as their doubts will be cleared.

Added recommendation is to carry out both vertical and horizontal job rotation. Under horizontal job rotation employees will be in teams at a similar level. For example, a finance executive will be working with a sales executive. Under vertical job rotation, a finance executive will be working with a finance manager. These will assist in obtaining a wider view of the business process and job role which will improve performance as employees are more knowledgeable and aware.

It can further be recommended to carry out mentoring sessions on a one-on-one basis where individual attention will be paid. This will be an opportunity for an individual to express his/her concerns personally without embarrassment. This will mitigate issues at a personal level which is directly linked to higher employee performance.

The main limitation of the research is that the sample had to be narrowed down to the above stated numbers due to practical difficulties. Including more respondents would have increased the reliability and reduced sampling error. Furthermore, it can be stated that using questionnaire to collect data resulted in problems like incomplete questionnaires. Apart from that, the respondents' thinking was limited to the given set of 
questions only. This limits creative thinking.

It could be recommended to carry out a research by considering mid-range apparel companies rather than the industry leaders as training and development is relatively low in those organizations due to budget, resource persons and time limitations as opposed to large scale apparel companies. The need for training and development will be higher in these mid-sized companies. Furthermore, it can be recommended to include more independent variables such as outbound training which will provide a wider understanding. This would facilitate in further enhancing the validity of the research.

\section{CONCLUSION}

The main research objective was to identify how training and development affects employee performance in the context of the apparel industry in Sri Lanka. The selected independent variables were orientation training, coaching, job rotation, mentoring and continuous job training while the dependent variable was employee performance. These were analyzed in depth through the data collected. Through correlation and regression analysis, the significance of independent variables on employee performance was identified. Hence all the hypotheses set in the research were accepted in this study, denoting that independent variables play a vital role on employee performance. The null hypothesis for all the determinants were not supported proving that there is a relationship between all the independent variables and the dependent variables. Based on the data gathered recommendations were made as to what practical steps be followed in enhancing employee performance such as carrying out orientation training in a simulated environment, pre-informing about coaching sessions, carrying out oneto-one mentoring sessions and undertaking vertical and horizontal job rotations. Based on the above stated data, it could be confidently mentioned that all the research objectives were successfully achieved within the given scope. Finally, it could be drawn that when orientation training, coaching, job rotation, mentoring and continuous job training are increased, employers will be able to increase performance of the workforce. The research is significant as it facilitates employers to understand how they could use training and development and how it affects job performance. This research could also facilitate employers in paying more attention on developing effective and comprehensive use training and development programs.

\section{REFERENCES}

Ardley, B. \& Mcintosh, E. (2019). Business strategy and business environment: The impact of virtual communities on value creation. Strategic Change, 28(5), 325-331.

Abdul, A. K. (2011). Impact Of Training And Development On Organizational Performance. Global Journal 
Of Management And Business Research.

Aidah, N. (2013). Effects Of Training On Employee Performance Eveidence From Uganda. Vaasan Ammattikorkeakoulu University Of Applied Sciences.

Armstrong, M. (2006). A Handbook Of Human Resource Management Practice. Kogan Page Limited.

Bukovinsky, D. (2013). Are Pay-ForPerformance systems missing the mark? Journal of Human Resources Management.

Charles, K. O. (2009). Mployee Training And Development Program At The Coca-Cola Bottling Company Of Ghana Kumasi. University Of Cape Coast.

Densten, I. L. \& Sarros, J. C. (2012). The impact of Organizational culture and social desirability on Australian CEO Leadership. Leadership \& Organization Development Journal, 33(4).

Divina, M. E. (2004). Training: A Strategichrm Function. Notes On Business Education, Pp. $1-4$

Jacqueline, R. (2003). What Role Can A Training Needs Analysis Play In Organisational Change? .
Juliana, S. M. (2004). Training And Development Techniques For Improving Organizationalperformance For Ghanaian Firms. Menomonie: University Of Wisconsin-Stout.

Mengistu, B. (2011). Effect Oftraining And Development On Employee Performance And Organizational Effectiveness. Addis Ababa University.

Muthiani, A. M. (2013). Perceived Relationship Between Employee Development Programs And Organisational Commitment At Barclays Bank Of Kenya.

Olaniyan, D. A. (2008). Staff Training And Development: A Vital Tool For Organisational Effectiveness. European Journal Of Scientific Research , 326331.

Raymond, A. N. (2010). Employee Training And Development. Paul Ducham.

Sultana, A. S. I. (2012). Impact Of Training On Employee Performance: A Study Of Telecommunication Sector In Pakistan. Interdisciplinary Journal of Contemporary Research In Business , 640661.

Tahir, I. K. (2014). The Impact Of Training And Development On Employees. International 
Gammanpila D. D., Kodisinghe K.A.M.S., Wayamba Journal of Management 11 (2)

Journal Of Academic

Research In Business And

Social Sciences, 86,98. 